\title{
Mechanical Transmission and Physical Properties of Mungbean Yellow Mosaic Virus (MYMV)
}

\author{
Meghashree Meti $^{1}$, Mallikarjun Kenganal ${ }^{1 *}$, D.S. Aswathanarayana ${ }^{1}$, \\ U.K. Shanwad ${ }^{2}$ and Gururaj Sunkad ${ }^{1}$ \\ ${ }^{1}$ Department of Plant Pathology, ${ }^{2}$ Department of Agronomy, University of Agricultural \\ Sciences, Raichur, Karnataka, India \\ *Corresponding author
}

\section{A B S T R A C T}

\section{Keywords}

MYMV, Mechanical transmission, Physical properties, TIP, DEP and LIV

Article Info

Accepted:

16 February 2018

Available Online:

10 March 2018
Begamoviruses are usually considered not transmissible by mechanical sap inoculation and hence making information about their physical properties scarce which are useful in determining management strategies. The present study was conducted to know sap transmissibility and physical properties of Mungbean Yellow Mosaic Virus (MYMV) like Thermal Inactivation Point (TIP), Dilution End Point (DEP) and Longevity in vitro (LIV). The infective sap prepared in potassium phosphate and sodium phosphate buffers of $\mathrm{pH}$ 7.5, 7.6, 7.7, 7.8, 7.9 and 8.0 at $0.1 \mathrm{M}$ inoculated on French bean and mungbean revealed that $0.1 \mathrm{M}$ potassium phosphate buffer at $7.8 \mathrm{pH}$ could successfully transmit MYMV on French bean under glass house conditions. The determination of physical properties using the same buffer showed Thermal Inactivation Point (TIP) of MYMV as $50{ }^{0} \mathrm{C}$ for 10 minutes, Dilution End Point (DEP) was $10^{-4}$ and Longevity in vitro (LIV) was 1-2 days at $4{ }^{0} \mathrm{C}$ storage in vitro. The results add to the knowledge of MYMV transmission ability and its physical properties which helps in determining management strategies against the virus.

\section{Introduction}

Yellow mosaic disease in pulses is caused by Mungbean Yellow Mosaic Virus (MYMV) which is most destructive in Indian subcontinent and adjacent areas of South-East Asia causing 100 per cent yield losses (Kang et al., 2005). The MYMV in India was first time reported by Nariani in 1960 from IARI (Indian Agricultural Research Institute), New Delhi fields with an incidence of 20-30 per cent. Several others reported the occurrence and severity of MYMV from other parts of
India, Sri Lanka, Pakistan, Bangladesh, New Guinea, Philippines and Thailand (Honda et al., 1983; Chenulu and Verma, 1988; Malik and Bashir, 1992; Jones, 2003; Ahmad and Harwood, 1973). MYMV infects mungbean, soybean, mothbean, cowpea, urdbean and few other leguminous hosts (Dhingra and chenulu, 1985 and Qazi et al., 2007). Mungbean yellow mosaic virus belongs to the family Geminiviridae (Geminate means twin particles) consisting of viruses with circular (20 x $30 \mathrm{~nm})$, single-stranded (ss) DNA genome (Hull, 2004). It belongs to genus 
Begomovirus transmitted by whitefly (Bemisia tabaci Genn.) vector (Haq et al., 2011) and has remained challenge for decades since its destructive nature is known among mungbean growers and scientists also.

Management of virus diseases requires indepth understanding of virus, host range, vectors, mode of transmission and physical properties etc. which enable in designing sound management strategies. Often to inhibit the virus multiplication, it is essential to know the physical properties of virus like, thermal inactivation point (TIP), dilution end point (DEP) and longevity In vitro (LIV). Physical properties of viruses help in making management decisions and opportunities for further research. However, most of the begamoviruses are reported to be transmitted by whitefly vectors not by any other means. The curiosity to understand the physical properties cannot be achieved unless the virus proved to be sap transmissible. Many attempts were made to transmit MYMV mechanically but were futile. There is only one report of successful transmission by Honda et al., (1983). Otherwise, there are no reports from India or elsewhere. Thus keeping in view the importance of MYMV disease and losses caused, the present study was conducted to standardize the mechanical transmission of MYMV and understand its behavior in response to temperature, dilutions and it vitro storage.

\section{Materials and Methods}

There is lack of information related to physical properties of MYMV like Thermal Inactivation Point (TIP), Dilution End Point (DEP) and Longevity in vitro (LIV) which could help researchers in managing the virus and other related studies. In order to develop a mechanical transmission procedure for MYMV and to know its physical properties, the present experiments were carried out following the methodology described by
Noordam (1973). In the present investigation $0.1 \mathrm{M}$ potassium phosphate (Honda et al., 1983 ) and $0.1 \mathrm{M}$ sodium phosphate buffers at $\mathrm{p}^{\mathrm{H}}$ 7.5, 7.6, 7.8, 7.9 and 8.0 were tried for mechanical sap inoculation of MYMV on mungbean and French bean. Potassium phosphate buffer of $\mathrm{p}^{\mathrm{H}} \quad 7.8$ was found successfully transmitting the MYMV on French bean but not on mungbean. Hence, $0.1 \mathrm{M}$ potassium phosphate buffer of $\mathrm{p}^{\mathrm{H}} 7.8$ was used further for physical properties study.

\section{Buffer preparations}

Potassium dihydrogen phosphate $\left(\mathrm{KH}_{2} \mathrm{PO}_{4}\right)$ and dipotassium hydrogen phosphate $\left(\mathrm{K}_{2} \mathrm{HPO}_{4}\right)$ were used for phosphate buffer preparation. Sodium dihydrogen phosphate $\left(\mathrm{NaH}_{2} \mathrm{PO}_{4}\right)$ and disodium hydrogen phosphate $\left(\mathrm{Na}_{2} \mathrm{HPO}_{4}\right)$ were used for sodium phosphate buffer. In preparation of both the buffers of different $\mathrm{pH}, 0.1 \mathrm{M}$ respective chemicals were prepared separately. About $50 \mathrm{ml}$ of dipotassium hydrogen of each was taken in a clean glass beaker and drop wise dihydrogen phosphate of each was added by intermittently checking the $\mathrm{pH}$ till the desired $\mathrm{pH}$ level was reached. Similar practice was followed while preparing all the buffers of respective chemical and $\mathrm{pH}$ level. To each buffer of $100 \mathrm{ml} 50 \mu \mathrm{l}$ of $\beta$ mercaptoethanol was added as a reducing agent to prevent the inactivation of virus particles.

\section{Virus inoculum}

Pure virus culture was raised on mungbean plants grown under glass house in caged net. The virus infested mungbean leaf samples were collected from field and virus was transmitted on healthy mungbean seedlings using whiteflies. The leaves of mungbean plants in glass house showing mosaic symptoms were used as fresh inoculum for extraction of infective crude sap. The inoculum was prepared by grinding virus infected young mungbean leaves, 
approximately $1 \mathrm{gm}$ of infected leaf sample was taken in a pre-chilled morter, to this $2 \mathrm{ml}$ of buffer was added and ground finely using the pestle. The pure sap was obtained by filtering the ground sap through muslin cloth and collected in a beaker. The sap was mixed with a pinch of celite as an abrasive. Sterilized cotton was used for making small pad, dipped in it to the sap and applied gently on 10 days old French bean seedlings on the upper 2-3 leaves. The leaves were held on palm between the fingers from below to give support. Cotton pad dipped in inoculum was rubbed from mid rib towards margin of the leaves to avoid any physical damage. Five minutes after inoculation, leaves were washed with a jet of water using wash bottle, for each treatment, five plants were inoculated, all the plants were labeled and placed in glass house for incubation till symptoms expression. Same procedure of mechanical transmission was followed for determining the ideal buffer for mechanical transmission of MYMV and also for determination of physical properties.

\section{Determining physical properties}

\section{Dilution end point (DEP):}

Infective sap was diluted in buffer from $10^{-1}$ to $10^{-7}$ following serial dilution technique. All these dilutions were inoculated on 10 days old French bean seedlings immediately, undiluted sap was used as positive control and only buffer as negative control, for each dilution, 5 plants were inoculated and kept in glass house under insect proof cages. Observations on symptoms expressed and days taken to symptom expression were recorded.

\section{Thermal inactivation point (TIP):}

The TIP was determined by subjecting $2 \mathrm{ml}$ of sap to different temperatures treatment separately viz., 35, 40, 45, 50, 55 and $60^{\circ} \mathrm{C}$ for 10 minutes in hot water bath. Treated sap were inoculated on 10 days old French bean seedlings, for each temperature treatment, five seedlings were inoculated, untreated sap was used a positive control and only buffer as negative control, treated plants were kept in glass house for incubation. Observations on symptoms expressed and days to symptom expression were recorded for each treatment.

\section{Longevity in vitro (LIV):}

Sufficient quantity of infective sap was extracted from infected leaf material. $5 \mathrm{ml}$ of infective sap in each test tube was dispensed and total 14 tubes were prepared. 7 tubes were kept at $4{ }^{0} \mathrm{C}$ and other 7 at $25{ }^{0} \mathrm{C}$ (room temperature). Freshly extracted sap was immediately inoculated on 10 days old 5 French bean seedlings as control ( 0 day) which was also positive control and buffer alone inoculated served as negative control. Among the stored tubes one tube from each stored at $4{ }^{0} \mathrm{C}$ and $25{ }^{0} \mathrm{C}$ were taken out regularly at $2,5,10,15,20,25$ and 30 days after storage (DAS) and inoculated on 10 days old 5 French bean seedlings separately. The inoculated seedlings were kept under insect proof cages in glass house. Observations on symptoms expressed and time taken for symptoms expression were recorded.

\section{Results and Discussion}

Virus diseases are often most threatening due to their systemic nature of infection and transmission by vectors. Until the basic information of virus such as physical properties, mode of transmission, alternate hosts etc. are known, management of the virus is highly difficult. The current study to determine the physical properties of Mung Bean Yellow Mosaic Virus (MYMV) which is not yet undertaken in India revealed very useful information and facts not known earlier. Reports on successful transmission of MYMV through mechanical means itself are very rare, however in the present investigation it was found successfully transmitting on 10 
days old French bean seedlings by mechanical transmission method using $0.1 \mathrm{M}$ potassium phosphate buffer at $7.8 \mathrm{pH}$ (Table 1), which is in concurrence with the findings of Honda $e t$ al., (1983) who also concluded that French bean may also be used as propagative host for MYMV. Sodium phosphate buffer failed in mechanical transmission of MYMV irrespective of $\mathrm{pH}$ levels. Studies on physical properties of MYMV such as Thermal Inactivation Point (TIP), Dilution End Point (DEP) and Longevity In vitro (LIV) were done following sap transmission method on French bean seedlings of 10 days old, which expressed symptoms of MYMV such as curling, crinkling, mild mosaic and chlorotic spots (Plate 1).

Determination of Thermal Inactivation Point (TIP) showed positive transmission of virus when sap was treated at $35,40,45$ and $50{ }^{\circ} \mathrm{C}$ temperatures. Plants inoculated with treated sap showed downward curling, crinkling of leaves, chlorotic spots and mild mosaic symptoms. In all the treatments, symptoms were noticed at 28 to 30 days after inoculation. In case of untreated sap, similar symptoms were observed at 25 to 28 days after inoculation. Symptoms were absent on plants inoculated with sap treated at 55 and 60 ${ }^{0} \mathrm{C}$. These observations reveal that, MYMV retained the transmissibility at highest temperature of $50{ }^{\circ} \mathrm{C}$ but not beyond.

The temperature of 55 and $60{ }^{\circ} \mathrm{C}$ made the virus inactive (Table 2). Hence, the thermal inactivation point of MYMV is $50^{\circ} \mathrm{C}$ beyond which virus failed to produce any symptoms on inoculated host.

Table.1 Response of potassium and sodium phosphate buffers towards sap transmission of MYMV

\begin{tabular}{|c|c|c|c|c|}
\hline \multirow{2}{*}{$\begin{array}{c}\mathrm{pH} \\
\text { level }\end{array}$} & \multicolumn{2}{|c|}{ Potassium phosphate buffer } & \multicolumn{2}{|c|}{ Sodium phosphate buffer } \\
\hline & Mungbean & Frenchbean & Mungbean & Frenchbean \\
\hline & \multicolumn{4}{|c|}{ Transmission } \\
\hline 7.5 & $\mathrm{X}$ & $\mathrm{X}$ & $\mathrm{X}$ & $\mathrm{X}$ \\
\hline 7.6 & $\mathrm{X}$ & $\mathrm{X}$ & $\mathrm{X}$ & $\mathrm{X}$ \\
\hline 7.8 & $\mathrm{X}$ & $\sqrt{ }$ & $\mathrm{X}$ & $\mathrm{X}$ \\
\hline 7.9 & $\mathrm{X}$ & $\mathrm{X}$ & $\mathrm{X}$ & $\mathrm{X}$ \\
\hline 8.0 & $X$ & $X$ & $\mathrm{X}$ & $\mathrm{X}$ \\
\hline
\end{tabular}

Table.2 Effect of different temperatures on infectivity of MYMV

\begin{tabular}{|c|c|c|c|c|}
\hline Treatments & $\begin{array}{c}\text { Temperature } \\
\left({ }^{0} \mathrm{C}\right)\end{array}$ & Transmission & $\begin{array}{c}\text { No. of days to } \\
\text { symptom expression }\end{array}$ & $\begin{array}{l}\text { Symptoms } \\
\text { observed }\end{array}$ \\
\hline T1 & $\begin{array}{c}\text { Untreated sap } \\
\text { inoculation }\end{array}$ & + & $25-28$ & $\begin{array}{l}\text { Dc, Cl and } \\
\text { Cs }\end{array}$ \\
\hline T2 & 35 & + & 28 & $\mathrm{Dc}$ and Cl \\
\hline T3 & 40 & + & $28-30$ & $\mathrm{Dc}$ and Cl \\
\hline T4 & 45 & + & $28-30$ & $\mathrm{Cl}$ \\
\hline T5 & 50 & + & $28-30$ & $\mathrm{Cl}$ \\
\hline T6 & 55 & - & - & - \\
\hline T7 & 60 & - & - & - \\
\hline
\end{tabular}

Dc: Downward Curling, Cl: Crinkling of leaves, Cs: Chlorotic spots 
Table.3 Effect of different sap dilutions on infectivity of MYMV

\begin{tabular}{|c|c|c|c|c|}
\hline Treatments & Dilutions & Transmission & $\begin{array}{c}\text { No. of days to } \\
\text { express symptoms }\end{array}$ & $\begin{array}{c}\text { Symptoms } \\
\text { observed }\end{array}$ \\
\hline T1 & $10^{-1}$ & + & $26-28$ & $\mathrm{Cl}$ and Cs \\
\hline T2 & $10^{-2}$ & + & 28 & $\mathrm{Cl}$ \\
\hline T3 & $10^{-3}$ & + & 28 & $\mathrm{Cl}$ \\
\hline T4 & $10^{-4}$ & + & 28 & $\mathrm{MCl}$ \\
\hline T5 & $10^{-5}$ & - & - & - \\
\hline T6 & $10^{-6}$ & - & - & - \\
\hline T7 & $10^{-7}$ & - & - & - \\
\hline T8 & Control & + & 25 & $\mathrm{Cl}$ and Dc \\
\hline
\end{tabular}

Dc: Downward Curling, Cl: Crinkling of leaves, Cs: Chlorotic spots, $\mathrm{MCl}$ : Mild crinkling

Table.4 Effect of different in vitro storage conditions on infectivity of MYMV

\begin{tabular}{|c|c|c|c|c|c|c|}
\hline \multirow[t]{2}{*}{ Treatments } & \multirow{2}{*}{$\begin{array}{c}\text { Different } \\
\text { intervals } \\
\text { (days) }\end{array}$} & \multicolumn{2}{|c|}{$\begin{array}{l}\text { At room temperature } \\
\left(28^{\circ} \mathrm{C}\right)\end{array}$} & \multicolumn{2}{|c|}{$\begin{array}{l}\text { At refrigeration temperature } \\
\qquad\left(4^{\circ} \mathrm{C}\right)\end{array}$} & \multirow[t]{2}{*}{$\begin{array}{l}\text { Symptoms } \\
\text { observed }\end{array}$} \\
\hline & & $\begin{array}{c}\text { No of days to } \\
\text { symptoms } \\
\text { expression }\end{array}$ & $\begin{array}{l}\text { Transmis } \\
\text { sion }\end{array}$ & $\begin{array}{l}\text { No of days to } \\
\text { symptoms } \\
\text { expression }\end{array}$ & Transmission & \\
\hline T1 & 0 & 28 & + & 28 & + & $\mathrm{Dc}$ and $\mathrm{Cl}$ \\
\hline $\mathrm{T} 2$ & 2 & - & - & $28-30$ & + & $\mathrm{Cl}$ and $\mathrm{Cs}$ \\
\hline T3 & 5 & - & - & - & - & - \\
\hline T4 & 10 & - & - & - & - & - \\
\hline T5 & 15 & - & - & - & - & - \\
\hline T6 & 20 & - & - & - & - & - \\
\hline T7 & 25 & - & - & - & - & - \\
\hline T8 & 30 & - & - & - & - & - \\
\hline
\end{tabular}

Dc: Downward Curling, Cl: Crinkling of leaves, Cs: Chlorotic spots

Plate.1 (a) Expression of symptoms on French bean seedling by MYMV and (b) no symptoms in control plant inoculated with buffer
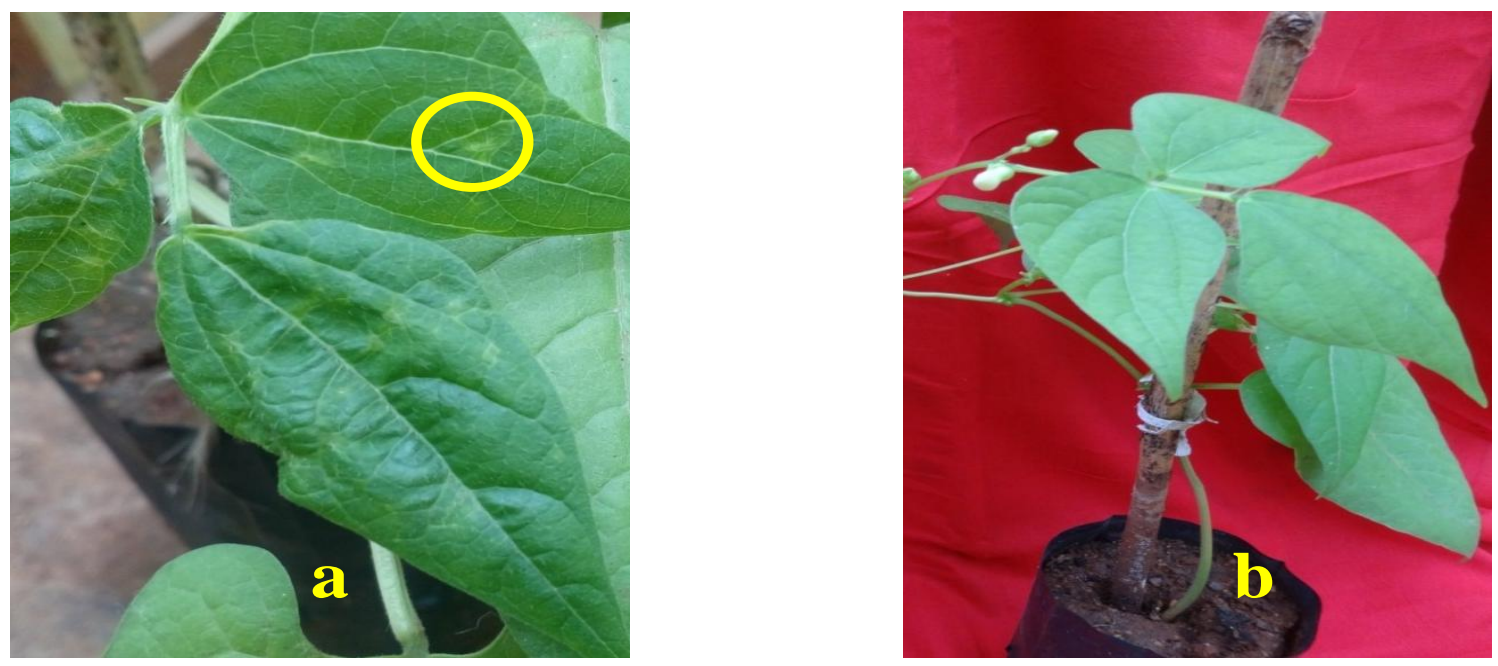
In determining the Dilution End Point (DEP), infective sap was subjected to serial dilutions up to $10^{-7}$ dilutions and inoculated on 10 days old French bean seedlings following mechanical (sap) transmission method along with undiluted control. The inoculated plants showed downward curling, mild mosaic and crinkling symptoms at $10^{-1}, 10^{-2}, 10^{-3}$ and $10^{-4}$ dilutions and also in undiluted control. No symptoms were noticed in further diluted sap at $10^{-5}, 10^{-6}$ and $10^{-7}$ (Table 3 ). The results conclude that virus retained its transmissibility up to $10^{-4}$ dilution (four times) with mild crinkling of leaves and mild mosaic but further dilutions failed to express virus symptoms, hence, the dilution end point of MYMV recorded is $10^{-4}$.

Longevity In vitro (LIV) was determined by storing the infective crude sap at $4{ }^{\circ} \mathrm{C}$ and 28 ${ }^{0} \mathrm{C}$. Like in TIP \& DEP, here also infective sap was inoculated to French bean seedlings at different days of intervals of 2, 5, 10, 15, 20, 25 and 30 days from the storage along with freshly extracted and inoculated control (0 day). Infective sap stored at $4{ }^{0} \mathrm{C}$ expressed symptoms of crinkling, mild mosaic and chlorotic spots on French bean after two days of storage but further storage reduced the infectivity and failed to produce any symptoms on French bean. None of the sap samples stored at $25{ }^{\circ} \mathrm{C}$ at any time interval showed symptoms (Table 4) indicating this temperature detrimental for storage of virus outside the host. The transmission was positive only at 2 days of storage at $4{ }^{0} \mathrm{C}$, thus the longevity in vitro of MYMV is 1-2 days at $4{ }^{0} \mathrm{C}$ temperature.

The previous studies conducted by Honda et al., (1983) supports our findings who reported that, TIP of MYMV is $40-50{ }^{\circ} \mathrm{C}$ for $10 \mathrm{~min}$, DEP of $10^{-2}$ to $10^{-3}$ and LIV of 1-2 days at 20 ${ }^{0}$ C. Bird et al., (1977) also studied physical properties of Euphorbia mosaic virus and reported the TIP of $55-60{ }^{\circ} \mathrm{C}$ for 10 minutes,
DEP of $10^{-3}$ and LIV of 24hrs. Another geminivirus Bean golden mosaic virus has recorded TIP at $50{ }^{\circ} \mathrm{C}$, DEP was $10^{-2}$ and LIV was 4 weeks (at $8{ }^{\circ} \mathrm{C}$ ). Markham and Smith (2009) studied physical properties of Turnip yellow mosaic virus and recorded DEP of $10^{-5}$ and TIP of 70-75 ${ }^{0} \mathrm{C}$. Physical properties of Tomato yellow leaf curl virus (TYLCV) was studied by Shorab et al., (2014) who reported its DEP of $10^{-8}$, TIP at 30 to $40{ }^{\circ} \mathrm{C}$ and LIV of 48 hours. It is evident from these previous reports that, most of the begomoviruses have TIP of within $50{ }^{\circ} \mathrm{C}$ and LIV of $48 \mathrm{hrs}$ and DEP up to $10^{-8}$ which is maximum among the reported studies. This gives a strong support and valid reason for their persistent nature of transmission by insects and non-viability outside the living host. In recent times inspite of increased global warming their incidences are towards increasing trend. The variability in their properties was mainly due to their adaptation to the local weather and cropping systems.

\section{References}

Ahmad, M. and Harwood, R. F. 1973. Studies on a whitefly-transmitted yellow mosaic of urdbean (Phaseolus mungo). Pl. Dis., 57: 800-802.

Bird, J., Monoller, A. C. and Sanchez, I. 1977. Properties of two viruses transmitted by the whitefly Bemisia tabaci Genn. in Puerto Rico. Phytopathol., 12 (1): 31-32.

Chenulu, V. V. and Verma, A. 1988. Virus and virus-like diseases of pulse crops commonly grown in India. In: Baldev, B., Ramanujam, S., Jain, H. K. (Eds.), Pulse Crops. Oxford and IBH, New Delhi, 338-370.

Dhingra, K. L. and Chenulu, V. V. 1985. Effect of yellow mosaic on yield and nodulation of soybean. Indian Phytopathol., 38: 248-251. 
Haq, Q. M. I., Arif, A. and Malathi V. G. 2011. Infectivity analysis of a blackgram isolate of mungbean yellow mosaic virus and genetic assortment with MYMIV in selective hosts. Virus Res., 42 (3):429-439.

Honda, Y., Iwaki, M. and Saito, Y. 1983. Mechanical transmission, purification and some properties of whitefly-borne mungbean yellow mosaic virus in Thiland. Pl. Dis., 67: 801-804.

Hull, R., 2004, Mathew's Plant Virology. Fourth Edition. Elsevier Publishers, India, pp.180-182.

Jeske, H. 2009. Geminiviruses. Curr Top Microbiol Immunol. 331: 185-226.

Jones, D. R. 2003. Plant viruses transmitted by whiteflies. European J. Pl. Pathol., 4 (1): 195-219.

Kang, B. C, Yeam, I. and Jahn M. M. 2005. Genetics of plant virus resistance. Annu Rev Phytopathol. 43: 581-621.

Malik, B. A. and Bashir, M. 1992. Major diseases of food legume crops of Islamic countries. In: Jamil, F. F., Naqvi, S.H.M. (Eds.), Proceedings of COMSTECH-NAIB International Workshop of Agroclimatology Pests and Disease and Their Control. Pp. 2538.

Mansoor, S., Briddon R. W., Zafar, Y., Stanley, J. 2003. Geminivirus disease complexes: an emerging threat. Trends Plant Sci. 8:128-134.

Markham, R and Smith, K. 2009. Studies on the virus of turnip yellow mosaic Parasitol., 39 (3): 330-342.

Nariani, T. K. 1960. Yellow mosaic of Mung (Phasoelus aureus L.). Indian Phytopathol., 13: 24-29.

Noordam, D. 1973. Identification of Plant Viruses: Methods and Experiments. Centre for Research and Documentation. Wageningen. pp. 5055.

Qazi, J., Ilyas, M., Manseor, S. and Briddan, R. W. 2007. Legume Yellow Mosaic Virus: genetically isolated begomovirus mole. Plant Patholo., 8 (4): 343-348.

Shorab, S. S., Karim, S. Varma, A., Abuzenadah, A. M., Chaudhary, A. G., Damanhouri, G. A. and Mandal, B. 2014. Characterization of Tomato Leaf Curl New Delhi Virus infecting cucurbits: Evidence for sap transmission in a host specific manner. Afr. $J$. Biotechnol., 12 (32): Pp. 5000-5009.

\section{How to cite this article:}

Meghashree Meti, Mallikarjun Kenganal, D.S. Aswathanarayana, U.K. Shanwad and Gururaj Sunkad. 2018. Mechanical Transmission and Physical Properties of Mungbean Yellow Mosaic Virus (MYMV). Int.J.Curr.Microbiol.App.Sci. 7(03): 1903-1909.

doi: https://doi.org/10.20546/ijcmas.2018.703.226 